\title{
Analisis Pengaruh Penambahan Penyulang Dan Pemisahan Beban Terhadap Susut Daya Menggunakan Metode Simple Branch Exchange (Studi Kasus PT PLN ULP Lima Puluh, Sumatera Utara)
}

\author{
Irnanda Priyadi, S.T.,M.T. ${ }^{*}$, Junas Haidi , S.T.,M.T. ${ }^{1}$, Chandra Sitohang ${ }^{1}$ \\ ${ }^{1}$ Program Studi Teknik Elektro, Fakultas Teknik, Universitas Bengkulu, Kota Bengkulu, Provinsi Bengkulu \\ irnanda_p@unib.ac.id
}

\begin{abstract}
During the distribution process there will be a loss of some of the energy that is channeled. This phenomenon is known as losses. This is caused by technical and non-technical factors. In the State Electricity Service (PLN) system, distribution losses or energy losses is calculated by measuring the difference between $\mathrm{kWh}$ produced and $\mathrm{kWh}$ sell. This $\mathrm{kWh}$ difference is the electrical energy lost during the starting process from the generation or secondary side of the Substation to customers' APP. Cumulatively, the amount of $\mathrm{kWh}$ at all base sources is 73,769.524 $\mathrm{kWh}$ while the distribution loss that occurs in JTM is $\mathbf{5 , 8 3 5 . 0 0 8}$ or $\mathbf{7 . 9 1 \%}$. One way to overcome and minimize distribution losses in the $20 \mathrm{kV}$ Procurement Service Unit (ULP) of Lima Puluh distribution system is to analyze the distribution network system, add new feeders and break the load on the electrical system. The simple branch exchange method is used to separate the network load, which is done by adding a switch by turning the on or off channel and searching for the configuration that produces the smallest power loss and calculating the power loss based on the network load. Based on the simulation results using the ETAP 12.6 software, the results of the energy loss of Procurement Service Unit (ULP) of Lima Puluh is $5,864,112 \mathrm{kWh}$ then decreased after load separation of $4,341,348 \mathrm{kWh}$. The value of power loss before load separation is $1,955 \mathrm{~kW}$ and a decrease in power loss after load separation is $1,484.5 \mathrm{~kW}$. The investment cost incurred for the construction of a new feeder is RP. $22,000,000,000$,- with a payback of 9.9 years.
\end{abstract}

Keywords: Feeder, Power Loss, Energy Loss, ETAP 12.6.

\section{Abstrak}

Selama proses distribusi akan terjadi hilangnya sebagian energi yang tersalur. Fenomena ini disebut dengan susut/losses. Hal tersebut diakibatkan oleh faktor teknis maupun faktor non-teknis. Pada sistem PLN, susut distribusi atau susut energi dihitung dengan mengukur selisih antara $\mathrm{kWh}$ produksi dan kWh jual. Selisih kWh ini merupakan energi listrik yang hilang selama proses mulai dari pembangkitan atau sisi sekunder Gardu Induk sampai dengan APP pelanggan. Secara kumulatif, besarnya kWh di seluruh pangkal sumber adalah 73.769,524 $\mathrm{kWh}$ sedangkan susut distribusi yang terjadi pada JTM sebesar 5.835,008 atau 7,91\% . Salah satu cara dalam mengatasi dan meminimalkan susut distribusi pada sistem distribusi 20 kV Unit Layanan Pengadaan (ULP) Lima Puluh adalah dengan menganalisis sistem jaringan distribusi, penambahan penyulang baru dan melakukan pecah beban sistem kelistrikan. Digunakan metode simple branch exchange untuk memisahkan beban jaringan yang dilakukan dengan cara menambahkan switch dengan mengubah on atau off saluran dan pencarian konfigurasi yang menghasilkan susut daya terkecil serta menghitung susut daya berdasarkan beban jaringan. Berdasarkan hasil simulasi menggunakan software ETAP 12.6 didapat hasil susut energi ULP Lima Puluh 5.864.112 kWh kemudian mengalami penurunan setelah pemisahan beban sebesar 4.341.348 $\mathrm{kWh}$. Nilai susut daya sebelum pemisahan beban sebesar $1.955 \mathrm{~kW}$ dan mengalami penurunan susut daya setelah pemisahan beban menjadi $1.484,5 \mathrm{~kW}$. Biaya investasi yang dikeluarkan untuk pembangunan penyulang baru sebesar RP. 22.000.000.000,- dengan pengembalian modal selama 9.9 tahun.

Kata kunci : Penyulang, Susut Daya, Susut Energi, ETAP 12.6.

\section{Pendahuluan}

Pada sistem PLN, susut distribusi atau susut energi dihitung dengan mengukur selisih antara $\mathrm{kWh}$ produksi dan $\mathrm{kWh}$ jual. Selisih kWh ini merupakan energi listrik yang hilang selama proses mulai dari pembangkitan atau 
sisi sekunder Gardu Induk sampai dengan Alat Pembatas dan Pengukur (APP) pelanggan. Secara kumulatif, besarnya $\mathrm{kWh}$ di seluruh pangkal sumber adalah $73,769,524 \mathrm{kWh}$ sedangkan susut distribusi kumulatif ULP Lima Puluh dimulai dari periode Januari 2019 sampai dengan Desember 2019 yaitu sebesar 8,394,739 $\mathrm{kWh}$ atau $11.38 \%$ dan susut distribusi yang terjadi pada JTM sebesar 5,835,008 atau 7,91\%. [1]

PT PLN (Persero) ULP Lima Puluh yang selanjutnya disebut dengan PLN Lima Puluh merupakan salah satu unit di PT PLN (Persero) UIW Sumatera Utara UP3 Pematang Siantar yang melakukan pendistribusian tenaga listrik kepada konsumen. PLN Lima Puluh memiliki wilayah kerja yang cukup luas yang mencakup sebagian wilayah Kabupaten Batu Bara dan sebagian wilayah Kabupaten Simalungun. Salah satu cara dalam mengatasi dan meminimalkan susut distribusi pada sistem distribusi $20 \mathrm{kV}$ ULP Lima Puluh adalah dengan menganalisis sistem jaringan distribusi, penambahan penyulang baru dan melakukan pecah beban sistem kelistrikan. Dalam usulan pecah beban dan penarikan penyulang baru ini terlebih dahulu dilakukan analisis/perhitungan susut teknis dengan menggunakan ETAP 12.6.

Dalam penelitian ini, digunakan metode simple branch exchange untuk memisahkan beban jaringan yang dilakukan dengan cara menambahkan switch dengan mengubah on atau off saluran dan pencarian konfigurasi yang menghasilkan susut daya terkecil serta menghitung susut daya berdasarkan beban jaringan. Berdasarkan perihal tersebut, maka secara empiris penyusun skripsi melihat adanya peluang berupa upaya penurunan susut daya di ULP Lima Puluh yakni dengan melakukan pisah beban dan penarikan penyulang baru $20 \mathrm{kV}$ terhadap penyulang SM05 dan SM07.

\section{Landasan Teori}

Penelitian ini bertujuan untuk melihat dampak penurunan susut daya/energi dari usulan rekonfigurasi penyulang di PLN ULP Lima Puluh. Susut daya (susut energi) merupakan besarnya daya yang hilang pada suatu jaringan pada proses pengiriman daya listrik dari sumber kepada beban. Penelitian dilakukan dengan cara membandingkan hasil simulasi sebelum dan sesudah penambahan penyulang baru dan pemecahan jaringan distribusi $20 \mathrm{kV}$ menggunakan perangkat lunak ETAP 12.6.0 (Electical Transient Analysis Program).

Hal yang dilakukan setelah melakukan simulasi pemisahan beban menggunakan software etap 12.6.0 adalah menghitung besar daya yang tersalurkan, susut daya dan susut energi mengunakan persamaan 1, 2 dan 3.[2-4]

$$
\text { P3 } \phi=\sqrt{3} \times \mathrm{V} \times \mathrm{I} \times \cos \phi(\mathrm{kW})
$$

Perhitungan losses sebagai berikut :

$$
\text { Ploss }=3 I^{2} \mathrm{R} \mathbf{l}(\mathrm{kW})
$$

(2)

Susut energi dapat dihitung menggunakan rumus

Eloss $=$ Ploss $\times$ h (Watt hour) $/ 1000(\mathbf{k W h})$

$\%$ Susut Energi $=\frac{\text { Total Susut Energi }}{\text { Total Energi Yang Tersalurkan }}$

\section{A. Metode Newton-Raphson}

Pada tahap awal, dilakukan penomoran bus terhadap sistem yang akan dianalisis. Bus-bus yang terhubung dengan generator diberi nomor terlebih dahulu setelah itu penomoran bus dilanjutkan pada bus-bus beban, bus yang memiliki kapasitas pembangkit terbesar dipilih sebagai sebagai slack bus dan diberi nomor satu, Untuk bus yang lain yang terhubung ke generator diberi nomor dua sebagai bus pembangkit dan bus beban diberi nomor 0 (nol).[5]

$$
\begin{aligned}
& P_{i}-j Q_{i}=\left|V_{i}\right| \angle-\delta_{i} \sum_{j=1}^{n} Y_{i j} V_{j} \angle \theta_{i j}+\delta_{j} \\
& P_{i}-j Q_{i}=\left|V_{i}\right| e^{-j \delta} \sum_{j=1}^{n} Y_{i j} V_{j} \angle\left(e^{j\left(\delta_{j}-\delta_{i}+\theta_{i j}\right)}\right) \\
& P_{i}=\sum_{j=1}^{n}\left|V_{i} V_{j} Y_{i j}\right| \cos \left(\delta_{j}-\delta_{i}+\theta_{i j}\right) \\
& Q_{i}=\sum_{j=1}^{n}\left|V_{i} V_{j} Y_{i j}\right| \cos \left(\delta_{j}-\delta_{i}+\theta_{i j}\right)
\end{aligned}
$$

\section{B. Pemisahan Beban}

Pemisahan beban merupakan salah satu fenomena yang terjadi di suatu sistem tenaga listrik yang mengizinkan adanya beban keluar dari sistem sehingga menghasilkan kestabilan sistem tenaga listrik. Hal ini biasanya disebabkan oleh adanya beban lebih pada sistem, sehingga untuk dapat mengembalikan kondisi sistem agar seperti sediakala diperlukan pemisahan beberapa beban tertentu.[6]

\section{Metode Simple Branch Exchange}

Tujuan utamanya adalah untuk mengurangi susut daya. Metode ini dilakukan penataan ulang saluran penghubung antar tiap bus yang terdapat pada penyulang sehingga penataan ulang saluran bisa mendapatkan profil tegangan yang baik dan kerugian daya yang minimal.

Metode ini hanya digunakan pada sistem distribusi dengan topologi jaringan radial. Berikut adalah gambar dari struktur sistem sistem radial :

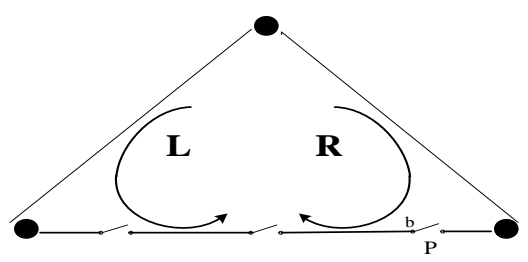

Gambar 2. Sistem Distribusi Radial

Dari Gambar 2 di atas dapat diketahui bahwa jika sectionalized switch $\mathrm{b}=$ closed, maka jaringan tersebut 
akan terjadi loop. Hal ini bertentangan dengan struktur sistem distribusi radial. Maka tiap sectionalized switch di sisi 1 atau $r$ harus dibuka agar tidak terbentuk loop pada jaringan. [7]

\section{Aplikasi ETAP 12.6}

ETAP merupakan perangkat lunak yang digunakan untuk melakukan perencanaan sistem kelistrikan yang ada di suatu industri atau wilayah. Software ini sangat bermanfaat untuk melakukan berbagai analisis yang sangat membantu untuk mempermudah pekerjaan. Dalam perancangan dan analisis sebuah sistem tenaga listrik, sebuah software aplikasi sangat dibutuhkan untuk merepresentasikan kondisi real sebelum sebuah sistem direalisasikan. ETAP merupakan salah satu perangkat lunak yang digunakan untuk mensimulasikan sistem tenaga listrik. [8].

\section{Metode dan Hasil Penelitian}

Diagram Alir Penelitian Sebagai Berikut

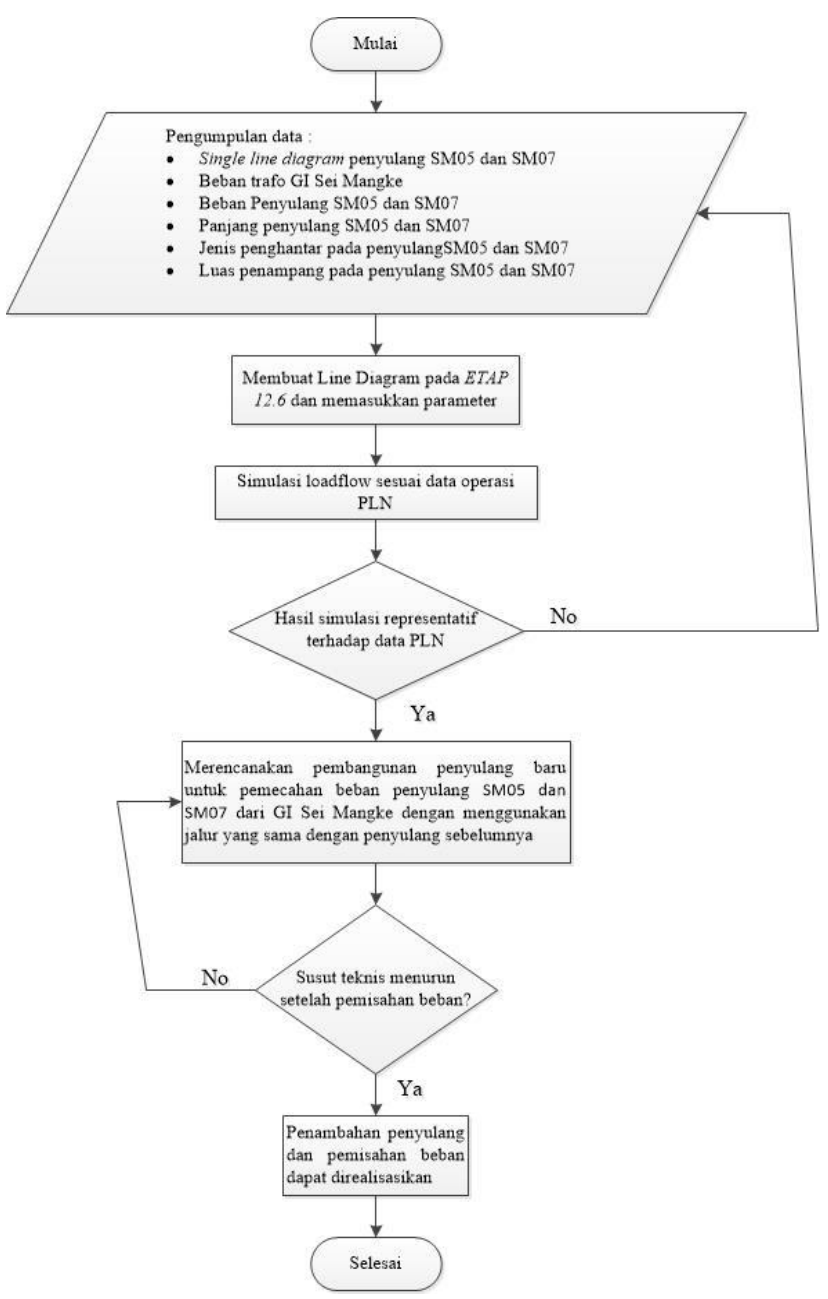

Gambar 1 Diagram Alir Penelitian

Selanjutnya data dan hasil pengolahan data hasil penelitian sebagai berikut :

\section{A. Konsisi Awal Penyulang SM 05}

Panjang keseluruhan jaringan penyulang SM 05 yakni $90.74 \mathrm{Kms}$ dan total gardu distribusi sebanyak 141 buah serta memiliki enam section. Section 1 menyuplai 44 trafo distribusi, Section 2 menyuplai 18 trafo distribusi, Section 3 menyuplai 22 trafo distribusi, Section 4 menyuplai 26 trafo distribusi, Section 5 menyuplai 16 trafo distribusi, dan Section 6 menyuplai 15 trafo distribusi.

Data pada Tabel 1 menunjukkan jenis konduktor saluran distribusi yang digunakan pada sistem jaringan penyulang SM 05 yaitu jenis konduktor AAAC dengan variasi ukuran $250 \mathrm{~mm}^{2}$ dan $150 \mathrm{~mm}^{2}$.Terdapat 6 section pada penyulang SM 05, dari data Tabel 2.Total keseluruhan susut daya pada penyulang SM 05 saat WBP sebesar $771.8 \mathrm{~kW}$ dan saat LWBP sebesar $254.8 \mathrm{~kW}$, sedangkan beban yang dipikul penyulang ini saat WBP adalah 215.2 A dan saat LWBP adalah 124.6 A. Untuk susut distribusi atau susut energi saat WBP sebesar $115.770 \mathrm{kWh}$ dan saat LWBP sebesar $145.236 \mathrm{kWh}$.

Tabel 1. Data Penghantar Saluran Distribusi SM 05

\begin{tabular}{|c|c|c|c|c|}
\hline Section & $\begin{array}{l}\text { Lokasi Beban Gardu } \\
\text { (Dari-Ke) }\end{array}$ & $\begin{array}{l}\text { Panjang } \\
(\mathrm{Km})\end{array}$ & $\begin{array}{c}\mathrm{R} \\
(\mathrm{Ohm})\end{array}$ & Penghantar \\
\hline 1 & $\begin{array}{l}\text { LBS PERLANAAN - } \\
\text { LBS LIMAPULUH }\end{array}$ & 14.944 & 0.1344 & $\begin{array}{c}\text { AAAC } 240 \\
\mathrm{~mm}^{2}\end{array}$ \\
\hline 2 & $\begin{array}{l}\text { LBS LIMAPULUH - } \\
\text { REC BW }\end{array}$ & 13.565 & 0.1344 & $\begin{array}{c}\text { AAAC } 240 \\
\mathrm{~mm}^{2}\end{array}$ \\
\hline 3 & $\begin{array}{c}\text { REC BW - LBS } \\
\text { ANTARA }\end{array}$ & 13.531 & 0.2162 & $\begin{array}{l}\text { AAAC } 150 \\
\mathrm{~mm}^{2}\end{array}$ \\
\hline 4 & $\begin{array}{l}\text { LBS ANTARA - FCO } \\
\text { SIMP. LAMA }\end{array}$ & 13.124 & 0.2162 & $\begin{array}{l}\text { AAAC } 150 \\
\mathrm{~mm}^{2}\end{array}$ \\
\hline 5 & $\begin{array}{l}\text { FCO SIMP. LAMA - } \\
\text { LBS LIDAH TANAH }\end{array}$ & 13.225 & 0.2162 & $\begin{array}{l}\text { AAAC } 150 \\
\mathrm{~mm}^{2}\end{array}$ \\
\hline \multirow[t]{2}{*}{6} & $\begin{array}{l}\text { LBS LIDAH TANAH } \\
\text { - UJUNG }\end{array}$ & 12.355 & \multirow[t]{2}{*}{0.2162} & \multirow[t]{2}{*}{$\begin{array}{l}\text { AAAC } 150 \\
\mathrm{~mm}^{2}\end{array}$} \\
\hline & TOTAL & 90.744 & & \\
\hline
\end{tabular}

Tabel 2. Data Hasil Susut Penyulang SM 05 Sebelum Pisah

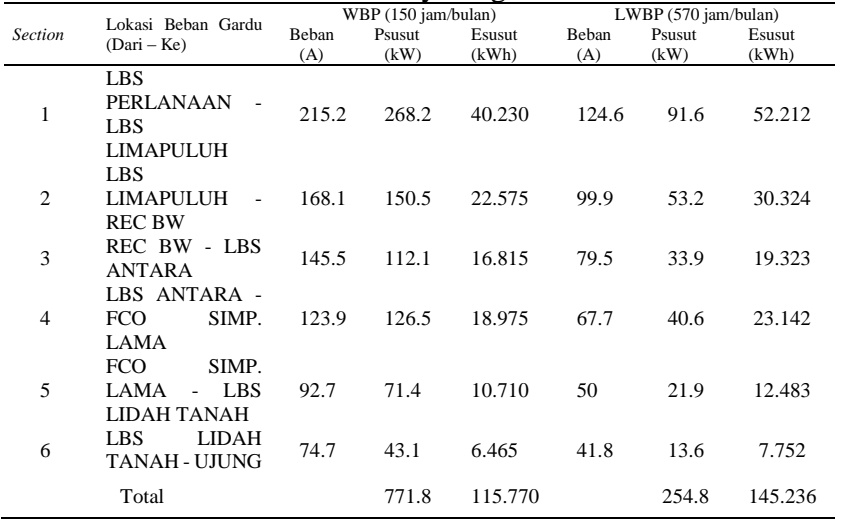

Dilakukan perhitungan manual susut daya menggunakan Persamaan 2 sebagai pembanding hasil simulasi yang telah dilakukan, hasil perhitungan manual susut daya dengan kondisi penyulang SM 05 sebelum pisah beban adalah sebagai berikut :

- Pada saat WBP 
Susut daya pada section 1, LBS PERLANAAN - LBS LIMAPULUH

$P=3 \times 215,2^{2}(0,1344) 14.944$

$P=2.076 .217(0,1344)$

$P=279 k W$

Section selanjutnya menggunakan rumus yang sama

Psusut total $=279.0+154.6+115.5+130.7$

$$
+73.7+44.7=798.2 \mathrm{~kW}
$$

- Pada saat LWBP

Susut daya pada section 1, LBS PERLANAAN - LBS LIMAPULUH

$$
\begin{aligned}
& P=3 x 124.6^{2}(0,1344) 14.944 \\
& P=696.024(0,1344) \\
& P=93.5 \mathrm{~kW}
\end{aligned}
$$

Section selanjutnya menggunakan rumus yang sama

Psusut total $=93.5+54.6+34.5+39.0+21.4$

$$
+14.0=257.1 \mathrm{~kW}
$$

Simulasi pada jaringan SM05 yang didapat masih dalam kategori berhasil dikarenakan selisih perhitungan dan simulasi tidak jauh berbeda.

Sesuai dengan data hasil simulasi pada Tabel 2 nilai arus penyulang SM 05 adalah 215.2 A (WBP) dan 124.6 (LWBP) maka dari itu daya yang terpakai untuk penyulang SM 05 dapat dihitung menggunakan Persamaan 1

\section{- WBP}

$\boldsymbol{P}=\sqrt{\mathbf{3}} * V * I * \cos \varnothing$

$\boldsymbol{P}=\sqrt{3} * 20000 V * 215.2 A * 0.96$

$\boldsymbol{P}=7.156 \mathrm{~kW}$

$$
\text { - LWBP }
$$

$$
\boldsymbol{P}=\sqrt{\mathbf{3}} * \boldsymbol{V} * I * \cos \emptyset
$$$$
P=\sqrt{3} * 20000 V * 124.6 A * 0.96
$$

$P=4.143 \mathrm{~kW}$

$$
\text { - } \mathrm{WBP}+\mathrm{LWBP}
$$

\section{$P=11.299 \mathrm{~kW}$}

Maka daya yang terpakai pada penyulang SM 05 adalah hasil penjumlahan dari pemakaian daya saat WBP dan LWBP yaitu $11.299 \mathrm{~kW}$.

\section{B. Konsisi Awal Penyulang SM 07}

Panjang keseluruhan jaringan penyulang SM 07 yakni $141.89 \mathrm{kms}$ dan total gardu distribusi sebanyak 157 buah serta memiliki enam section. Section 1 menyuplai 29 trafo distribusi, Section 2 menyuplai 25 trafo distribusi, Section 3 menyuplai 27 trafo distribusi, Section 4 menyuplai 24 trafo distribusi, Section 5 menyuplai 28 trafo distribusi, dan Section 6 menyuplai 24 trafo distribusi.

Data pada Tabel 3 menunjukkan jenis konduktor saluran distribusi yang digunakan pada sistem jaringan penyulang SM 05 jenis konduktor AAAC dengan variasi ukuran $250 \mathrm{~mm}^{2}$ dan $150 \mathrm{~mm}^{2}$ hingga $35 \mathrm{~mm}^{2}$.
Berdasarkan Tabel 4Terdapat enam section yang ada pada penyulang SM 07. Dari data tabel tersebut section pertama adalah section dengan susut daya yang paling besar pada saat WBP sebesar $300.9 \mathrm{~kW}$ dan saat LWBP sebesar $90 \mathrm{~kW}$.

Dilakukan perhitungan manual susut daya menggunakan Persamaan 2 sebagai pembanding hasil simulasi yang telah dilakukan,

- Pada saat WBP

Susut daya pada section 1, LBS LBS BINARIA - SEI BEJANGKAR

$P=3 x 185.9^{2}(0,1344) 21.5$

$P=2.229 .043(0,1344)$

$P=299.5 \mathrm{~kW}$

Untuk section selanjutnya dapat dihitung dengan

\begin{tabular}{|c|c|c|c|c|}
\hline Section & $\begin{array}{c}\text { Lokasi Beban } \\
\text { Gardu (Dari - } \\
\text { Ke) }\end{array}$ & $\begin{array}{c}\text { Panjang } \\
(\mathrm{Km})\end{array}$ & $\begin{array}{c}\mathrm{R} \\
(\mathrm{Ohm})\end{array}$ & Penghantar \\
\hline 1 & $\begin{array}{c}\text { LBS LBS } \\
\text { BINARIA - } \\
\text { SEI } \\
\text { BEJANGKAR }\end{array}$ & 21.50 & 0.1344 & $\begin{array}{c}\text { AAAC } 240 \\
\mathrm{~mm}^{2}\end{array}$ \\
\hline 2 & $\begin{array}{c}\text { LBS SEI } \\
\text { BEJANGKAR } \\
\text { - SIMP. ES }\end{array}$ & 23.35 & 0.1344 & $\begin{array}{c}\text { AAAC } 240 \\
\mathrm{~mm}^{2}\end{array}$ \\
\hline 3 & $\begin{array}{c}\text { LBS } \\
\text { MANGKE- } \\
\text { UJUNG }\end{array}$ & 20 & 0.4608 & $\begin{array}{c}\text { AAAC } 70 \\
\mathrm{~mm}^{2}\end{array}$ \\
\hline 4 & $\begin{array}{l}\text { LBS SIMP. ES } \\
\text { - LBS PG. } \\
\text { BOSI } \\
\text { LBS PG. }\end{array}$ & 21.35 & 0.4608 & $\begin{array}{c}\text { AAAC } 50 \\
\mathrm{~mm}^{2}\end{array}$ \\
\hline 5 & $\begin{array}{c}\text { BOSI-FCO } \\
\text { SORDANG } \\
\text { BOLON } \\
\text { FCO }\end{array}$ & 25.35 & 0.9217 & $\begin{array}{c}\text { AAAC } 35 \\
\mathrm{~mm}^{2}\end{array}$ \\
\hline 6 & $\begin{array}{l}\text { SORDANG } \\
\text { BOLON- } \\
\text { UJUNG }\end{array}$ & 20.33 & 0.9217 & $\begin{array}{c}\text { AAAC } 35 \\
\text { mm }^{2}\end{array}$ \\
\hline & Total & 141.89 & & \\
\hline
\end{tabular}
persamaan yang sama, maka susut total adalah

Psusut total $=299.6+124.9+139.4+94.6$

\begin{tabular}{|c|c|c|c|c|c|c|c|}
\hline \multirow[b]{2}{*}{ Section } & \multirow{2}{*}{$\begin{array}{c}\text { Lokasi Beban } \\
\text { Gardu (Dari - } \\
\text { Ke) } \\
\end{array}$} & \multicolumn{3}{|c|}{ WBP (150 jam/bulan) } & \multicolumn{3}{|c|}{ LWBP (570 jam/bulan) } \\
\hline & & $\begin{array}{l}\text { Beban } \\
\text { (A) }\end{array}$ & $\begin{array}{c}\text { Psusut } \\
(\mathrm{kW})\end{array}$ & $\begin{array}{l}\text { Esusut } \\
(\mathrm{kWh})\end{array}$ & $\begin{array}{l}\text { Beban } \\
\text { (A) }\end{array}$ & $\begin{array}{c}\text { Psusut } \\
(\mathrm{kW})\end{array}$ & $\begin{array}{l}\text { Esusut } \\
(\mathrm{kWh})\end{array}$ \\
\hline 1 & $\begin{array}{c}\text { LBS LBS } \\
\text { BINARIA - } \\
\text { SEI } \\
\text { BEJANGKAR }\end{array}$ & 185.9 & 300.9 & 45.135 & 103.9 & 90.0 & 51.300 \\
\hline 2 & $\begin{array}{l}\text { LBS SEI } \\
\text { BEJANGKAR } \\
\text { - SIMP. ES } \\
\text { LBS }\end{array}$ & 115.2 & 125.1 & 18.765 & 54.5 & 27.5 & 15.675 \\
\hline 3 & $\begin{array}{l}\text { MANGKE- } \\
\text { UJUNG } \\
\text { LBS SIMP }\end{array}$ & 71 & 139.5 & 20.925 & 49.8 & 66.2 & 37.734 \\
\hline 4 & $\begin{array}{l}\text { ES - LBS PG. } \\
\text { BOSI }\end{array}$ & 56.6 & 94.2 & 14.130 & 24.9 & 17.6 & 10.032 \\
\hline 5 & $\begin{array}{l}\text { LBS PG. } \\
\text { BOSI-FCO } \\
\text { SORDANG } \\
\text { BOLON }\end{array}$ & 23.7 & 39.5 & 5.925 & 9.6 & 6.4 & 3.648 \\
\hline
\end{tabular}

- Pada saat LWBP

$$
+39.4+19=716.9 k W
$$

Psusut total $=93.6+28.0+68.6+18.3+6.5$

$$
+2.9=214.9 k W
$$

Tabel 3. Data Penghantar Saluran Distribusi SM 07

Tabel 4. Data Hasil Penyulang SM 07 Sebelum Pisah Beban 


6 \begin{tabular}{ccccccc} 
FCO \\
$\begin{array}{c}\text { SORDANG } \\
\text { BOLON- } \\
\text { UJUNG } \\
\text { Total }\end{array}$ & 18.4 & 18.7 & 2.805 & 7.2 & 2.8 & 1.596 \\
\hline
\end{tabular}

Sesuai dengan data hasil simulasi pada Tabel 4 nilai beban penyulang SM 07 dipangkal penyulang adalah 185.9 A (WBP) dan 103.9 A (LWBP) maka dari itu daya yang terpakai untuk penyulang SM 07 dapat dihitung menggunakan Persamaan 1

- WBP

$\boldsymbol{P}=\sqrt{\mathbf{3}} * \boldsymbol{V} * I * \cos \emptyset$

$P=\sqrt{3} * 20000 V * 185.9 A * 0.96$

$P=6.182 \mathrm{~kW}$

- LWBP

$P=\sqrt{3} * V * I * \cos \varnothing$

$P=\sqrt{3} * 20000 V * 103.9 * 0.96$

$P=3.455 \mathrm{~kW}$

- $\mathrm{WBP}+\mathrm{LWBP}$

$P=9.637 \mathrm{~kW}$

Daya yang tersalurkani pada penyulang SM 07 adalah $9.637 \mathrm{~kW}$.

\section{Analisis Hasil Simulasi Sebelum Pisah Beban}

Berdasarkan hasil perhitungan simulasi yang telah dilakukan dapat dilihat bahwa nilai susut energi yang terjadi pada sistem Jaringan Tegangan Menengah (JTM) Sesuai dengan data hasil simulasi susut energi untuk kedua penyulang adalah $5.864 .112 \mathrm{kWh}$ dan nilai energi yang tersalurkan dari GI Sei Mangke untuk kedua penyulang sesuai dengan data PLN adalah 73.769.524 $\mathrm{kWh}$, maka dari itu persentase susut energi yang terjadi pada ULP Lima Puluh dapat dihitung.

a. Penyulang SM 05 (dalam 1 tahun)

Eloss WBP $=115.770 \mathrm{kWh} \times 12$ bulan $=1.389 .240 \mathrm{kWh}$

Eloss LWBP $=145.236 \mathrm{kWh} \times 12$ bulan $=1.292 .220 \mathrm{kWh}$

b. Penyulang SM 07 (dalam 1 tahun)

Eloss WBP $=107.685 \mathrm{kWh} \times 12$ bulan $=1.742 .832 \mathrm{kWh}$

Eloss LWBP $=119.985 \mathrm{kWh} \times 12$ bulan $=1.439 .820 \mathrm{kWh}$

Eloss Total $=1.389 .240 \mathrm{kWh}+1.292 .220 \mathrm{kWh}$

$$
+1.742 .832 \mathrm{kWh}+1.439 .820 \mathrm{kWh}
$$

Eloss Total $=5.864 .112 \mathrm{kWh}$ dalam 1 tahun

$\%$ susut energi $=\left(\frac{5.864 .112 k W h}{73.769 .524 \mathbf{k W h}}\right) * 100 \%$

$\%$ susut energi $=7.9 \%$

Berdasarkan hasil perhitungan persentase susut energi yang terjadi pada ULP Lima Puluh adalah 7.9 \%.

\section{Kondisi Setelah Penambahan Penyulang}

Hal yang dilakukan untuk menekan susut daya pada sistem kelistrikan ULP Lima Puluh dilakukan pemisahan sebagian beban penyulang SM 05 dan SM 07 ke penyulang baru atau Express Feeder. Dengan adanya penambahan penyulang baru, maka beban yang dipikul oleh penyulang SM 05 dan SM 07 akan berkurang. Pemecahan beban dilakukan pada titik LBS Lima Puluh sampai Rec. BW pada penyulang SM 05 dan beban pada LBS Mangke yang ada pada penyulang SM 07 akan dilimpahkan kepada penyulang baru, sehingga akan terjadi perubahan kondisi jaringan pada penyulang SM 05 dan penyulang SM 07. Penyulang baru ini memerlukan kabel sepanjang $10 \mathrm{kms}$ sebagai penghubung saluran dari GI Sei Mangke sampai ke LBS Mangke sehingga panjang keseluruhan saluran untuk penyulang baru $58.509 \mathrm{Kms}$ dan total trafo distribusi sebanyak 67 trafo.

Dengan adanya penambahan penyulang baru, maka beban yang dipikul oleh penyulang SM 05 dan SM 07 akan berkurang. Pemecahan beban dilakukan pada titik beban yang telah dipilih sehingga akan terjadi perubahan kondisi jaringan pada penyulang SM 05 dan penyulang SM 07. Penyulang baru ini memerlukan kabel sepanjang $10 \mathrm{kms}$ sebagai penghubung saluran dari GI Sei Mangke sampai ke LBS Mangke sehingga panjang keseluruhan saluran untuk penyulang baru $58.509 \mathrm{kms}$.

Tabel 5. Data Hasil SimulasiPenyulang Baru

\begin{tabular}{|c|c|c|c|c|c|c|c|}
\hline \multirow[b]{2}{*}{$\begin{array}{l}\text { Sectio } \\
n\end{array}$} & \multirow[b]{2}{*}{$\begin{array}{c}\text { Lokasi Beban } \\
\text { Gardu (Dari - } \\
\mathrm{Ke})\end{array}$} & \multicolumn{3}{|c|}{ WBP $(150$ jam $)$} & \multicolumn{3}{|c|}{ LWBP (570 jam) } \\
\hline & & $\begin{array}{c}\text { Beba } \\
\text { n } \\
\text { (A) }\end{array}$ & $\begin{array}{c}\text { Psusut } \\
(\mathrm{kW})\end{array}$ & $\begin{array}{l}\text { Esusut } \\
(\mathrm{kWh})\end{array}$ & $\begin{array}{c}\text { Beba } \\
n \\
\text { (A) }\end{array}$ & $\begin{array}{c}\text { Psusu } \\
\mathrm{t} \\
(\mathrm{kW})\end{array}$ & $\begin{array}{l}\text { Esusut } \\
(\mathrm{kWh})\end{array}$ \\
\hline 1 & $\begin{array}{c}\text { LBS } \\
\text { MANGKE- } \\
\text { UJUNG }\end{array}$ & $\begin{array}{c}67 . \\
2\end{array}$ & $\begin{array}{c}124 . \\
7\end{array}$ & $\begin{array}{c}18.70 \\
5\end{array}$ & $\begin{array}{c}48 . \\
4\end{array}$ & 62 & $\begin{array}{c}35.34 \\
0\end{array}$ \\
\hline 2 & $\begin{array}{c}\text { LBS } \\
\text { LIMAPULUH } \\
\text {-REC BW }\end{array}$ & $\begin{array}{c}58 . \\
3\end{array}$ & 20.7 & 3.105 & $\begin{array}{c}46 . \\
2\end{array}$ & $\begin{array}{c}12 . \\
3\end{array}$ & 7.011 \\
\hline 3 & $\begin{array}{c}\text { REC BW- } \\
\text { UJUNG }\end{array}$ & $\begin{array}{c}36 . \\
9\end{array}$ & 7.6 & 1.140 & $\begin{array}{c}26 . \\
3\end{array}$ & 3.7 & 2.109 \\
\hline & Total & & 153 & $\begin{array}{c}22.95 \\
0\end{array}$ & & 78 & $\begin{array}{c}44.46 \\
0\end{array}$ \\
\hline
\end{tabular}

Dilakukan perhitungan manual susut daya menggunakan Persamaan 2 sebagai pembanding keakuratan hasil simulasi dan perhitungan yang telah dilakukan, hasil perhitungan manual susut daya adalah sebagai berikut :

- Pada saat WBP

Susut daya pada section 1, LBS Mangke- Ujung

$P=3 x 67.2^{2}(0,4608) 20$

$P=270.950(0,4608)$

$P=124.9 \mathrm{~kW}$

Section selanjutnya menggunakan rumus yang sama

Psusut total $=124.9+20.5+7.4=152.8 \mathrm{~kW}$

- Pada saat LWBP

Susut daya pada section 1, LBS Mangke - Ujung

$P=3 x 48.4^{2}(0,4608) 20$

$P=140.553(0,4608)$

$P=64.8 \mathrm{~kW}$

Section selanjutnya menggunakan rumus yang sama

Psusut total $=64.8+12.9+3.8=81.4 k W$

Sesuai dengan data hasil simulasi pada tabel 5 nilai beban penyulang baru dipangkal penyulang adalah 185.9 
A (WBP) dan 103.9 A (LWBP) maka dari itu daya yang terpakai untuk penyulang baru dapat dihitung menggunakan Persamaan 1

- WBP

$\boldsymbol{P}=\sqrt{\mathbf{3}} * \boldsymbol{V} * I * \cos \emptyset$

$\boldsymbol{P}=\sqrt{3} * 20000 \mathrm{~V} * 67.2 A * 0.96$

$P=2.235 \mathrm{~kW}$

- LWBP

$\boldsymbol{P}=\sqrt{\mathbf{3}} * \boldsymbol{V} * I * \cos \varnothing$

$\boldsymbol{P}=\sqrt{3} * 20000 V * 48.4 * 0.96$

$P=1.610 \mathrm{~kW}$

- $\mathrm{WBP}+\mathrm{LWBP}$

$P=3.844 \mathrm{~kW}$

Maka daya yang terpakai exp. feeder yaitu $3.844 \mathrm{~kW}$.

E. Sistem Jaringan Penyulang SM 05 Setelah Pisah Beban

Panjang penyulang SM 05 setelah pemisahan beban menjadi $84.23 \mathrm{kms}$ dan memasok beban ke trafo distribusi sebanyak 101 buah trafo. Section 1 menyuplai 44 trafo distribusi, Section 2 menyuplai 26 trafo distribusi, Section 3 menyuplai 16 trafo distribusi, Section 4 menyuplai 15 trafo distribusi.

Dengan adanya penambahan penyulang baru yang mengakibatkan pengurangan beban pada penyulang SM 05. Hal ini diproyeksikan untuk mengurangi susut daya yang ada pada penyulang SM 05. Panjang saluran section 2 dan section 3 yang dipindahkan ke Exp. Feeder adalah $27.09 \mathrm{kms}$ dengan jumlah keseluruhan trafo distribusi 40 buah. Data impedansi, diameter konduktor, dan panjang saluran setelah pemisahan beban ke penyulang baru.

Tabel 6 menunjukkan nilai susut daya dengan simulasi pada penyulang SM 05 Susut daya pada penyulang SM 05 tertinggi berada pada section 1 yaitu $293.1 \mathrm{~kW}$ saat WBP dan $87.1 \mathrm{~kW}$ saat LWBP. Susut energi yang ada pada penyulang ini sebesar $80.145 \mathrm{kWh}$ saat WBP dan 91.884 kWh saat LWBP.

Dilakukan perhitungan manual susut daya menggunakan Persamaan 2 sebagai pembanding hasil simulasi yang telah dilakukan, hasil perhitungan manual susut daya dengan kondisi penyulang SM 05 sebelum pisah beban :

- Pada saat WBP

Susut daya pada section 1, LBS PERLANAAN LBS ANTARA

$P=3 x 166.9^{2}(0,1344) 25.531$

$P=2.133 .544(0,1344)$

$P=286.7 \mathrm{~kW}$

section selanjutnya dihitung dengan persamaan yang sama

Ptotal $=286.7+123.2+69.6+42.1$

$$
=521.7 \mathrm{~kW}
$$

- $\quad$ Pada saat LWBP
Ptotal $=85.4+37.8+20.8+13.6=157.6 \mathrm{~kW}$

Sesuai dengan data hasil simulasi pada tabel 7 nilai beban penyulang SM 05 dipangkal penyulang adalah 166.9 A (WBP) dan 91.1A (LWBP) maka dari itu daya yang terpakai untuk penyulang SM 05 setelah pemisahan beban dapat dihitung menggunakan Persamaan 1

- WBP

$\boldsymbol{P}=\sqrt{3} * \boldsymbol{V} * I * \cos \varnothing$

$P=\sqrt{3} * 20000 V * 166.9 A * 0.96$

$P=5.550 \mathrm{~kW}$

- LWBP

$\boldsymbol{P}=\sqrt{3} * \boldsymbol{V} * I * \cos \varnothing$

$P=\sqrt{3} * 20000 V * 91.1 * 0.96$

$P=3.030 \mathrm{~kW}$

$\mathrm{WBP}+\mathrm{LWBP}$

$P=8.580 \mathrm{~kW}$

Energi yang tersalurkan pada Penyulang SM 05 setelah pemisahan beban adalah penjumlahan WBP dan LWBP yaitu $8.580 \mathrm{~kW}$.

\begin{tabular}{|c|c|c|c|c|c|c|c|}
\hline \multirow[b]{2}{*}{$\begin{array}{l}\text { ctio } \\
n\end{array}$} & \multirow[b]{2}{*}{$\begin{array}{l}\text { Lokasi Beban Gardu } \\
\quad(\text { Dari }- \text { Ke })\end{array}$} & \multicolumn{3}{|c|}{ WBP $(150$ jam $)$} & \multicolumn{3}{|c|}{ LWBP (570 jam) } \\
\hline & & $\begin{array}{c}\text { Beba } \\
\text { n } \\
\text { (A) }\end{array}$ & $\begin{array}{c}\text { Psusu } \\
\mathrm{t} \\
(\mathrm{kW})\end{array}$ & $\begin{array}{l}\text { Esusut } \\
(\mathrm{kWh})\end{array}$ & $\begin{array}{c}\text { Beba } \\
n \\
\text { (A) }\end{array}$ & $\begin{array}{c}\text { Psusu } \\
\mathrm{t} \\
(\mathrm{kW})\end{array}$ & $\begin{array}{l}\text { Esusut } \\
(\mathrm{kWh})\end{array}$ \\
\hline 1 & $\begin{array}{l}\text { LBS PERLANAAN - } \\
\text { LBS ANTARA }\end{array}$ & 166.9 & 293.1 & $\begin{array}{c}43.96 \\
5\end{array}$ & 91.1 & 87.1 & $\begin{array}{c}49.64 \\
7\end{array}$ \\
\hline 2 & $\begin{array}{l}\text { LBS ANTARA - FCO } \\
\text { SIMP. LAMA }\end{array}$ & 120.3 & 126.1 & $\begin{array}{c}18.91 \\
5\end{array}$ & 66.6 & 38.2 & $\begin{array}{c}21.77 \\
4\end{array}$ \\
\hline 3 & $\begin{array}{l}\text { FCO SIMP. LAMA - } \\
\text { LBS LIDAH TANAH }\end{array}$ & 90.1 & 71.9 & $\begin{array}{c}10.78 \\
5\end{array}$ & 49.3 & 21.8 & $\begin{array}{c}12.42 \\
6\end{array}$ \\
\hline 4 & $\begin{array}{l}\text { LBS LIDAH TANAH } \\
\text { - UJUNG }\end{array}$ & 72.5 & 43.2 & 6.480 & 41.2 & 14.1 & 8.037 \\
\hline & Total & & 534.3 & $\begin{array}{c}80.14 \\
5\end{array}$ & & 161.2 & $\begin{array}{c}91.88 \\
4\end{array}$ \\
\hline
\end{tabular}

\section{F. Sistem Jaringan Penyulang SM 07 Setelah Pemisahan Beban}

Panjang penyulang SM 07 setelah pemisahan beban menjadi $121.89 \mathrm{kms}$ dan memasok beban ke trafo distribusi sebanyak 130 buah trafo. Section 1 menyuplai 29 trafo distribusi, Section 2 menyuplai 25 trafo distribusi, Section 3 menyuplai 24 trafo distribusi, Section 4 menyuplai 28 trafo distribusi, dan Section 5 menyuplai 24 trafo distribusi.

Dengan adanya penambahan penyulang baru yang mengakibatkan pengurangan beban pada penyulang SM 07 dimana beban pada LBS Mangke - ujung dipindahkan ke Exp. Feeder. Hal ini diproyeksikan untuk mengurangi susut daya yang ada pada penyulang SM 07. Panjang saluran LBS Mangke - ujung yang dipindahkan ke Exp. Feeder adalah $20 \mathrm{kms}$ dengan jumlah keseluruhan trafo distribusi 27 buah.

Setelah dilakukan simulasi aliran daya maka dapat diketahui susut yang terjadi pada penyulang SM 07 . Seperti yang terlihat pada Tabel 7 Susut keseluruhan penyulang SM 07 pada saat WBP adalah $466 \mathrm{~kW}$ dan pada saat LWBP $92 \mathrm{~kW}$ sedangkan susut terbesar ada pada section 3 saat WBP yaitu $143.8 \mathrm{~kW}$. Adapun beban 
yang dipikul penyulang SM 07 setelah pemisahan beban sebesar 119.2 A, nilai ini sudah jauh berkurang dari sebelum pemisahan beban.

Kemudian dilakukan perhitungan manual susut daya sebagai pembanding hasil simulasi yang telah dilakukan, hasil perhitungan manual :

- Pada saat WBP

Susut daya pada section 1, LBS BINARIA - SEI

BEJANGKAR

$P=3 \times 119.2^{2}(0,1344) 21.5$

$P=913.384(0,1344)$

$P=122.8 \mathrm{~kW}$

Ptotal $=122.8+133.8+142.4+42.8+20.5=462.2 \mathrm{~kW}$

- $\quad$ Pada saat LWBP

Susut daya pada section 1, LBS BINARIA - SEI BEJANGKAR

$P=3 \times 54.5^{2}(0,1344) 21.5$

$P=191.581(0,1344)$

$P=25.7 \mathrm{~kW}$

Ptotal $=25.7+27.5+25.8+6.6+2.9=88.5$

Tabel 7. Susut Daya Sistem Distribusi Penyulang SM 07

\begin{tabular}{|c|c|c|c|c|c|c|c|}
\hline \multirow[b]{2}{*}{ Section } & \multirow[b]{2}{*}{$\begin{array}{c}\text { Lokasi Beban } \\
\text { Gardu (Dari - Ke) }\end{array}$} & \multicolumn{3}{|c|}{ WBP (150 jam/bulan) } & \multicolumn{3}{|c|}{ LWBP (570 jam/bulan) } \\
\hline & & $\begin{array}{l}\text { Beban } \\
\text { (A) }\end{array}$ & $\begin{array}{c}\text { Psusut } \\
(\mathrm{kW})\end{array}$ & $\begin{array}{l}\text { Esusut } \\
(\mathrm{kWh})\end{array}$ & $\begin{array}{l}\text { Beban } \\
\text { (A) }\end{array}$ & $\begin{array}{c}\text { Psusut } \\
(\mathrm{kW})\end{array}$ & $\begin{array}{l}\text { Esusut } \\
(\mathrm{kWh})\end{array}$ \\
\hline 1 & $\begin{array}{c}\text { LBS BINARIA - } \\
\text { SEI BEJANGKAR } \\
\text { LBS SEI }\end{array}$ & 119.2 & 123.9 & 18.585 & 54.5 & 26.9 & 15.333 \\
\hline 2 & $\begin{array}{l}\text { BEJANGKAR - } \\
\text { SIMP. ES }\end{array}$ & 119 & 135.1 & 20.265 & 54 & 28.5 & 16.245 \\
\hline 3 & $\begin{array}{l}\text { LBS SIMP. ES - } \\
\text { LBS PG. BOSI } \\
\text { LBS PG. BOSI- }\end{array}$ & 58.7 & 143.8 & 21.570 & 25 & 26.9 & 15.333 \\
\hline 4 & $\begin{array}{l}\text { FCO SORDANG } \\
\text { BOLON }\end{array}$ & 24.7 & 42.6 & 6.390 & 9.7 & 6.7 & 3.819 \\
\hline 5 & $\begin{array}{l}\text { FCO SORDANG } \\
\text { BOLON- UJUNG }\end{array}$ & 19.1 & 20.6 & 3.090 & 7.2 & 3 & 1.710 \\
\hline & Total & & 466 & 69.900 & & 92 & 52.440 \\
\hline
\end{tabular}

Data hasil simulasi pada Tabel 7 nilai beban penyulang SM 07 dipangkal penyulang adalah 119.2 A (WBP) dan 54.5A (LWBP) maka dari itu daya yang terpakai untuk penyulang SM 07 dapat dihitung menggunakan Persamaan 1

- WBP

$\boldsymbol{P}=\sqrt{\mathbf{3}} * V * I * \cos \varnothing$

$P=\sqrt{3} * 20000 V * 119.2 A * 0.96$

$P=3.964 \mathrm{~kW}$

- LWBP

$\boldsymbol{P}=\sqrt{\mathbf{3}} * \boldsymbol{V} * \boldsymbol{I} * \cos \emptyset$

$\boldsymbol{P}=\sqrt{3} * 20000 \mathrm{~V} * 54.5 * 0.96$

$P=1.812 \mathrm{~kW}$

- $\mathrm{WBP}+\mathrm{LWBP}$

$P=5.776 \mathrm{~kW}$

Daya yang tersalurkan pada SM 07 adalah $5.776 \mathrm{~kW}$.

\section{G. Analisis Hasil Simulasi Setelah Pisah Beban}

Dilakukan perhitungan persentase susut energi dan susut daya pada ULP Lima Puluh setelah pemisahan beban, perhitungan persentase dapat dilihat sebagai berikut :

a. Penyulang Baru (dalam 1 tahun)

Eloss $\mathrm{WBP}=22.950 \mathrm{kWh} \times 12$ bulan $=275.400 \mathrm{kWh}$

Eloss LWBP $=44.460 \mathrm{kWh} \times 12$ bulan $=533.520 \mathrm{kWh}$

b. Penyulang SM 05 (dalam 1 tahun)

Eloss WBP $=80.145 \mathrm{kWh} \times 12$ bulan $=961.740 \mathrm{kWh}$

Eloss LWBP $=91.884 \mathrm{kWh} \times 12$ bulan $=1.102 .608 \mathrm{kWh}$

c. Penyulang SM 07

Eloss WBP $=69.900 \mathrm{kWh} \times 12$ bulan $=838.800 \mathrm{kWh}$

Eloss LWBP $=52.440 \mathrm{kWh} \times 12$ bulan $=629.280 \mathrm{kWh}$

Eloss Total $=4.341 .348 \mathrm{kWh}$ (dalam 1 tahun)

Persentase susut energi pada ULP Lima Puluh adalah

$\%$ susut energi $=\left(\frac{4.341 .343 \mathrm{kWh}}{73.769 .524 \mathrm{kWh}}\right) * 100 \%$

$\%$ susut energi $=\mathbf{5 . 9} \%$

Berdasarkan hasil perhitungan persentase susut energi yang terjadi pada ULP Lima Puluh adalah 5.9\%.

\section{H. Perbandingan Sistem Jaringan Sebelum Dan Susudah Pemisahan Beban}

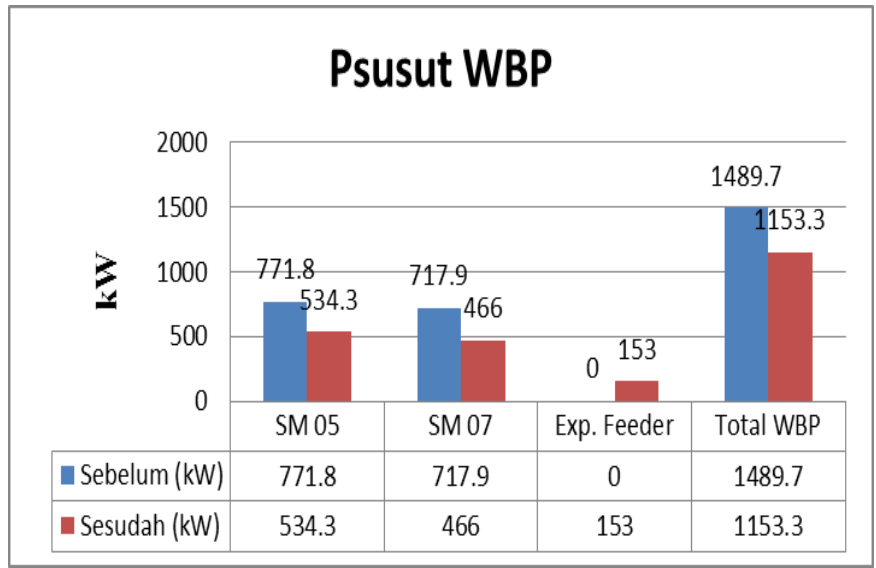

Gambar 3. Grafik Perbandingan Susut Daya Sebelum dan Sesudah saat WBP

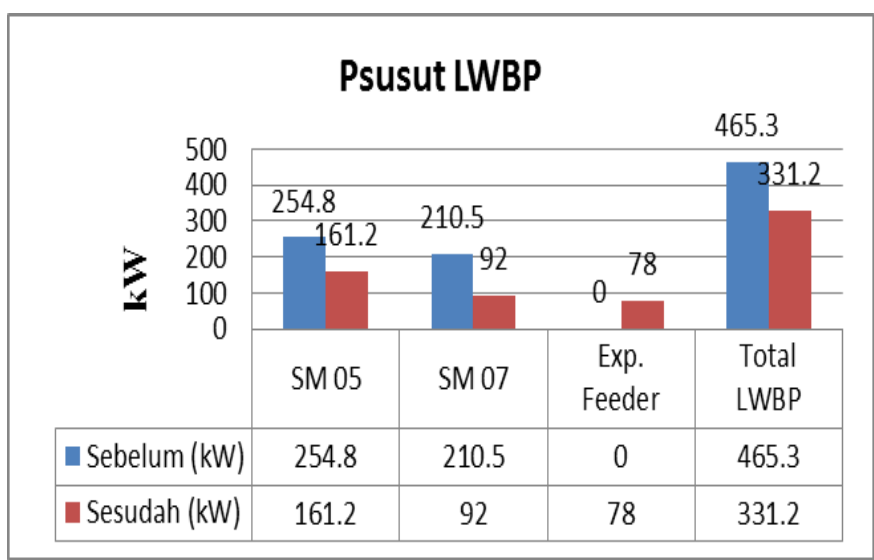

Gambar 4. Grafik Perbandingan Susut Daya Sebelum dan Sesudah saat LWBP 


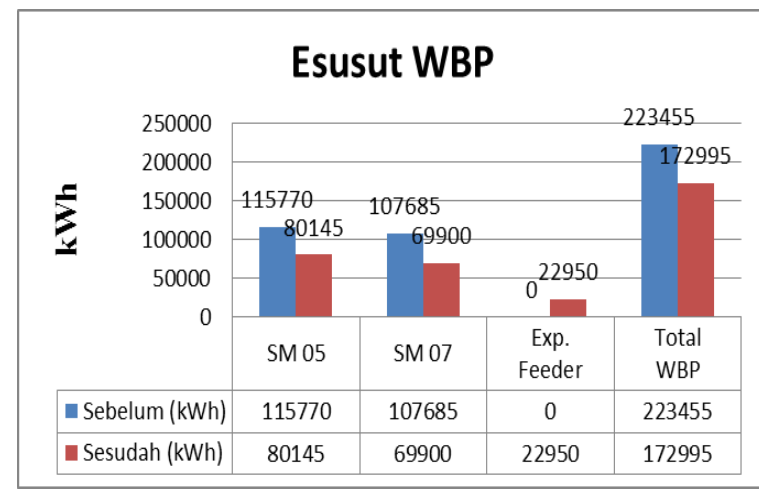

Gambar 5. Grafik Perbandingan Susut Energi Sebelum dan Sesudah saat WBP

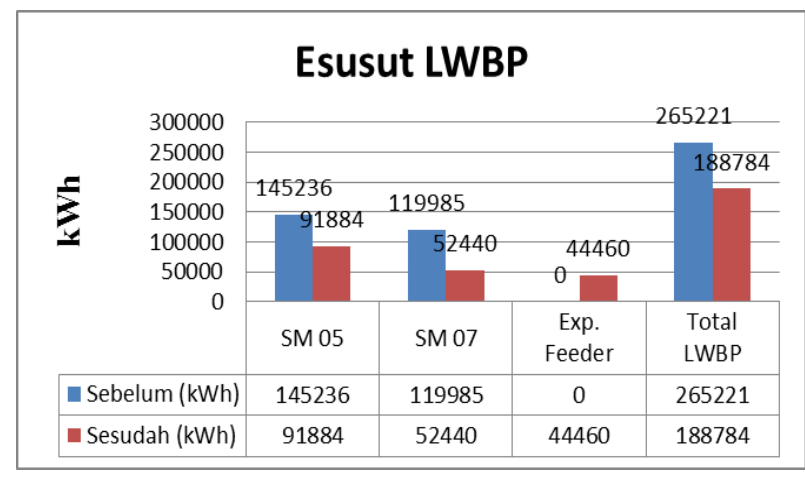

Gambar 6. Grafik Perbandingan Susut Energi Sebelum dan Sesudah saat LWBP

Perbandingan susut daya sebelum setelah dilakukannya pemisahan beban dapat dilihat Gambar 3 dan Gambar 4. Berdasarkan gambar grafik perbandingan ini dapat diketahui bahwa setelah dilakukan pemisahan beban pada setiap penyulang nilai susut daya mengalami perbaikan. Grafik berwarna merah lebih kecil dibandingkan dengan grafik yang berwarna biru yang membuktikan bahwa nilai susut daya pada beban mengalami penurunan. Berdasarkan grafik perbandingan ini dapat diketahui bahwa setelah dilakukan pemisahan beban nilai susut daya mengalami penurunan. Nilai susut daya secara total awalnya sebesar $1489.7 \mathrm{~kW}$ (WBP) dan $465.3 \mathrm{~kW}$ (LWBP) kemudian mengalami penurun menjadi $1153.3 \mathrm{~kW}$ (WBP) dan $331.2 \mathrm{~kW}$ (LWBP). Hasil ini membuktikan bahwa setelah dilakukan pemisahan beban terjadi penurunan susut daya sebesar $336,5 \mathrm{~kW}$ saat WBP dan 134,1 kW saat LWBP.

Perbandingan susut energi sebelum setelah dilakukannya pemisahan beban dapat dilihat Gambar 5 dan Gambar 6. Berdasarkan gambar grafik perbandingan ini dapat diketahui bahwa setelah dilakukan pemisahan beban pada tiap penyulang nilai susut energi mengalami penurunan. Nilai susut energi secara total awalnya sebesar $223.455 \mathrm{kWh}$ (WBP) 265.221 kWh (LWBP) kemudian mengalami penurun menjadi $172.955 \mathrm{kWh}$ (WBP) dan 188.784 (LWBP). Hasil ini membuktikan bahwa setelah dilakukan pemisahan beban pada setiap penyulang terjadi penurunan susut energi sebesar $50.500 \mathrm{kWh}$ (WBP) dan 76.784 (LWBP).

\section{Estimasi Biaya Investasi Penambahan Penyulang Dan Pemisahan Beban serta Break Even Point}

Pada penelitian ini penambahan penyulang memerlukan biaya untuk penambahan kabel penghantar SKT-TM (Saluran Kabel Tanah Tegangan Menengah) dengan panjang $12 \mathrm{kms}$ untuk penyulang SM 05 dan 10 kms untuk Exp feeder. Biaya penambahan kawat penghantar diestimasikan Rp.1.000.000.000,- per kms, biaya sudah termasuk biaya pemasangan, pemasangan penambahan kabel penghantar untuk penelitian ini sebagai berikut

\begin{tabular}{|c|c|c|c|}
\hline $\begin{array}{l}\text { Kabel XPLE } \\
\text { 240mm² untuk } \\
\text { Penyulang SM } 05\end{array}$ & $\begin{array}{l}12 \\
\mathrm{kms}\end{array}$ & $\begin{array}{l}\text { Rp. } \\
1.000 .000 .000,- \\
\text { per kms }\end{array}$ & Rp. $12.000 .000 .000,-$ \\
\hline $\begin{array}{l}\text { Kabel XPLE } \\
240 \mathrm{~mm}^{2} \text { untuk } \\
\text { Exp. Feeder }\end{array}$ & $\begin{array}{l}10 \\
\mathrm{kms}\end{array}$ & $\begin{array}{l}\text { Rp. } \\
1.000 .000 .000,- \\
\text { per kms }\end{array}$ & Rp. 10.000.000.000,- \\
\hline Total & $22 \mathrm{kms}$ & & Rp. 22.000.000.000,- \\
\hline
\end{tabular}

Biaya yang dibutuhkan untuk penambahan kabel penghantar sebesar Rp. 22.000.000.000,-. Biaya yang tertera sudah termasuk jasa pemasangan instalasi dan yang lainnya.

$$
\begin{aligned}
\text { Susut energi }= & 223.455 \mathrm{kWh}+265.221 \mathrm{kWh} \\
& =488.676 \mathrm{kWh}
\end{aligned}
$$

Susut energi sesudah penambahan penyulang saat WBP + LWBP

$$
\begin{aligned}
\text { Susut energi } & =172.955 \mathrm{kWh}+188.784 \mathrm{kWh} \\
& =361.779 \mathrm{kWh}
\end{aligned}
$$

Selisih antara sebelum dan sesudah penambahan penyulang

$$
\begin{aligned}
\text { Susut energi } & =488.676 \mathrm{kWh}-361.779 \mathrm{kWh} \\
& =126.897 \mathrm{kWh}
\end{aligned}
$$

Berdasarkan perhitungan susut energi antara sebelum dan sesudah yaitu sebesar $126.897 \mathrm{kWh}$, nilai ini merupakan susut energi bisa dihemat. Jika, di estimasikan biaya per-kWH sebesar Rp. 1.465,-

$$
\begin{aligned}
& 126.897 \mathrm{kWh} / \text { bulan } x 12 \text { bulan }=1.522 .764 \mathrm{kWh} / \text { tahun } \\
& \text { 1.522.764 kWh/tahun } x \text { Rp. } 1.465,-/=\text { Rp. } 2.230 .849 .260 \text {,- }
\end{aligned}
$$

Melakukan penambahan penyulang dan pemisahan beban pada sistem jaringan tegangan menengah ULP Lima Puluh akan menghemat pemakaian listrik sebesar 1.522.764 kWh/tahun atau Rp. 2.230.849.260,- dengan pemakaian listrik 5jam/hari saat WBP dan 19jam/hari saat LWBP.

Berdasarkan data diatas, biaya yang dikeluarkan untuk penyulang baru yaitu sebesar Rp. 22.000.000.000,-Pendapatan atau penghematan selama 1 tahun sebanyak Rp. 2.230.849.260,- sehingga :

Investasi dibagi dengan pendapatan selama 1 tahun 


\section{$\frac{\text { Rp.22.000.000.000, }-}{\text { Rp. 2.230.849.260, }-}=9.9$ tahun}

Waktu yang diperlukan untuk memperoleh kembali biaya investasi yang telah dikeluarkan yaitu 9.9 tahun.

\section{Kesimpulan}

1. Pada kondisi awal, berdasarkan hasil simulasi Software ETAP 12.6 susut daya dan susut energi pada ULP Lima Puluh adalah sebesar $1.955 \mathrm{~kW}$ dan $5.864 .112 \mathrm{kWh}$.

2. Dengan adanya penambahan Exp. Feeder dan pemisahan beban, nilai susut pada ULP Lima Puluh berkurang sebesar $470.5 \mathrm{~kW}$ untuk susut daya dan 1.522.764 kWh untuk susut energi.

3. Terjadi penurunan angka susut daya dan energi pada ULP Lima Puluh setelah penambahan penyulang dan pemisahan beban menggunakan metode simple branch exchange dengan besar susut $1.955 \mathrm{~kW}$ dan $5.864 .112 \mathrm{kWh}$ menjadi $1.484,5 \mathrm{~kW}$ dan 4.341 .348 $\mathrm{kWh}$.

\section{Referensi}

[1] ULP Lima Puluh. 2019. Data Susut Energi. Sumatera Utara : ULP Lima Puluh

[2]Yuana Dewi, Arfita. Asnal Effendi, dkk. 2017. Analisis Dampak Pemecahan Beban Feeder Tiku Terhadap Susut Teknis Jaringan Tegangan Menengah. Padang : Institut Negeri Padang.
[3]Waluyo, dkk. 2007. Perhitungan Susut Daya Pada Sistem Distribusi Tegangan Menengah Saluran Udara Dan Kabel. Jurnal Sains dan Teknologi EMAS. Vol.17 No.3. Bandung: Itenas Bandung.

[4] Nugroho, Aditya A., 2020, Analisis Pengaruh Penambanhan Penyulang MSR 13 Untuk Menengah Jatuh Tegangan Dan Rugi Daya Pada Penyulang SRN 03, FT Universitas Muhammadiyah Surakarta

[5] Gustiawan, Rahmat. 2018. Analisis Susut Daya Interkoneksi PLTM Hutaraja 2x2,5MW Terhadap Sistem Distribusi Siborong-Borong Sumatera Utara. Bengkulu : Universitas Bengkulu.

[6] Nandya. Made. 2014. Pemodelan Dan Simulasi Pemisahan Beban Pada Sistem Distribusi 20 Kv Berdasarkan Prioritas. Depok : Universitas Indonesia.

[7] Zhu, Jizhong. 2015. Optimization of Power System Operation. Canada.

[8] Multa P Lesnanto, Restu Prima Aridani. 2013. Modul Pelatihan ETAP. Yogyakarta : Jurusan Teknik Elektro Dan Teknologi Informasi Universitas Gadjah Mada.

[9] Fikri, M., Anggaini, D., 2018. Metode Newton Raphson Untuk Analisis Aliran Daya Jaringan Distribusi 12,66 kV. Jurnal Ilmiah SUTET, Vol. 8, No. 2, JuliDesember 2018, P-ISSN 2356-1505, E-ISSN 26569175

[1] [10] Sugianto, Untara. P., 2019. Studi Susut Energi Pada Sistem Distribusi Tenaga Listrik Melalui Analisis Pengukuran Dan Perhitungan. Jurnal Sinusoida Vol. XXI No. 2, April 2019 ISSN 1411 - 4593, Program Studi Teknik Elektro - ISTN 